\title{
The role of labour market experiences in the social and political integration of first and second-generation Non-Western and Eastern European immigrants in Ireland
}

Research Article

Tom Turner, and Christine Cross*

University of Limerick, Ireland

\begin{abstract}
The increase in the number of immigrants in Europe in recent decades has been accompanied by a rise in anti-immigrant sentiment and a growth in support for far-right political parties in Europe. A key element for ant-immigrant sentiment is the assumed lack of attachment and commitment of immigrants to the institutions, values and national identity of the host country. While a considerable body of studies have focused on the political and social assimilation of immigrants into European countries, the possible influence of Irish labour market experiences of first and second generation immigrants from non-western countries and Eastern European countries remains an under-researched area in the literature. Combining five waves of the European Social Survey we test the proposition that the labour market experiences of first and second-generation immigrants from non-western countries and Eastern European countries are a factor affecting the extent of political and social assimilation into the host country. Our findings indicate that first-generation immigrants' attachment to the political institutions of the host country are likely influenced more by a comparison with conditions in their country of origin rather than how they fare in labour market of the host country.
\end{abstract}

Keywords: immigrants, Europe, Ireland, social integration, political integration

(c) Sciendo

\section{INTRODUCTION}

A significant increase in migration occurred in most European Union (EU) countries in the latter part of the $20^{\text {th }}$ century; this includes countries previously characterised as emigrant countries such as Ireland, Italy and Spain (Garson and Loizillon, 2003). Immigrants are a significant feature in the demographic profile of Ireland accounting for almost 13 per cent of the population compared to an average of just over 10 percent in the majority of European Union countries (CSO, 2018; Fargues et al., 2011). European countries will increasingly depend on immigrant workers in the $21^{\text {st }}$ century due to a combination of demographic changes and the highly segmented labour market and differentiated economies (OECD, 2003; Hix and Noury, 2007; Finch et al., 2009). However various Eurobarometer surveys indicate that the trend in attitudes towards immigrants is far from positive. In the late 1980s a Eurobarometer survey indicated that 30 percent of respondents believed there were too many foreigners in their country; ten years later this figure had increased to 41 percent (Lahav, 2004: 86). Such negative attitudes to immigrants are often based on mostly groundless economic fears that significant inflows of foreign workers will increase unemployment, depress wages and lead to a decline in the employment of national workers and nebulous cultural fears of a dilution of national identity and social customs and values (Borjas, 2006; Borjas et al., 1997; OECD, 2001).

For workers who vote for right wing populist parties it appears that perceived threats to community and identity are more decisive than economic grievances (Oesch, 2008). Anti-immigrant sentiment has taken the form of violent protests and riots in countries such as France and there has been a notable rise in support for far-right political parties in Europe (Rustenbach, 2010). European respondents who hold negative attitudes are more likely to believe that new immigrants contaminate the values and traditions that comprise their country's national identity by diluting 
it with the values, culture and traditions of alien societies (Zick et al., 2011; Cicero Pereira et al., 2009; Sassen, 1999). Sentiment is particularly antagonistic towards immigrants from outside Europe and non-western countries generally - a trend that is universal among European countries (Murray, 2017; Butkus et al., 2016). Non-western immigrants such as those with an Islamic background are perceived as a threat to European values and inimical to a democratic system of government (see Dahl et al., 2001 - quoted in Yilmaz, 2012: 371). This is a fundamental issue as attachment of immigrants to the political civic values of democracy can be regarded as a vital aspect of their integration into European democracies (De Rooij, 2012).

Using a number of waves from the European Social Survey we first explore whether such negative sentiment towards immigrants from non-western and Eastern European countries has any evidential basis by comparing the political and social values of first-generation immigrants with native Irish respondents. From the mid-1990s to 2007 Ireland experienced unprecedented economic growth with a corresponding expansion in employment. For policy makers and employers, immigration helped satisfy labour shortages as Ireland was essentially transformed from a country of emigration to one of net immigration. Most of the inward flows can be attributed to the Irish government's decision not to restrict entry of the $10 \mathrm{EU}$ accession States in 2004. Immigrants accounted for just 2 per cent of the employed labour force in 1994 but this figure reached 16 per cent by 2006 (CSO, 2006). When economic growth slumped and Ireland was the first euro-zone country to enter a recession in early 2008 (Kollewe, 2008), it might have been expected that many migrants would return home. However, immigrants still accounted for 12 per cent of the employed labour force in 2010 (CSO, 2011).

Secondly this paper focuses on an under researched area of the association between the labour market experiences of first- and second-generation immigrants from non-western and Eastern European countries and commitment to fundamental political and social institutions. We specifically examine whether the labour market experiences of first and second-generation immigrants from non-western countries and Eastern European countries are a factor affecting the extent of political and social assimilation into the host country of Ireland. An explicit premise here is that experiences in the labour market are a significant determinant in the social and economic integration of immigrants' particularly non-western migrants into the host society. We begin by examining immigrant experiences in the labour market.

\section{LABOUR MARKET EXPERIENCES AND RELATIVE DEPRIVATION}

In capitalist market societies a worker's position or situation in the labour market is a crucial determinant of their life chances (Weber, 1978; Goldthorpe, 1992). Life chances refer to an individual's odds of sharing in the cultural and economic goods that exist in any given society (Giddens, 1973: 130-131). Sharing in the economic and cultural goods of a society is dependent on the characteristics of an individual's occupation such as income level, working conditions, degree of job security and the prospects for economic advancement (Breen, 2005: 46). There is considerable evidence from many countries that a substantial proportion of professional and skilled immigrants suffer from deskilling despite possessing high levels of education and qualifications (Brandi, 2001; Liversage, 2009). Local experience and country specific skills strongly privilege native born nationals in the labour market (Liversage, 2009; Friedberg, 2000; Barret et al., 2008: 16). A significant number of immigrants appear to suffer discrimination in the workplace and are more prone to be unemployed than comparable native workers and experience the negative effects of an economic crisis to a greater extent than native workers (Krings and Olivares, 2007; Evers and Van der Fier, 1998; Fix et al., 2009). In particular immigrants to Europe from Sub-Saharan Africa, North Africa, South America and Asia are more likely than others to believe that they belong to a group that is discriminated against on the grounds of race, ethnicity or nationality and have poorer job prospects than natives (Liebig et al., 2013; Friedberg, 2000; McMcKay et al., 2011).

Compared to natives a greater proportion of immigrants including those from Eastern European countries in the Irish labour market tend to work in precarious type employments, characterised by lower pay, fewer benefits, job insecurity in low-skill occupations and experience a sizeable wage gap and a lack of control of work tasks (Barrett et al., 2006; Barrett and McCarthy, 2007; Moriarty et al., 2015; Krings et al., 2011).

In this paper we use the concept of relative deprivation as a framework to examine the relationship between these labour market experiences and the social and economic integration of particular groups of immigrants (Hernes and 
Knudsen, 1992). A feeling of deprivation refers to the gap between what an individual believes they are entitled to, and what they receive. It can be defined as 'the conscious experience of a negative discrepancy between legitimate expectations and present actualities' (Schaefer, 2008: 69). Feelings of deprivation come from a comparison with perceived social norms that can vary over time and place, and not to absolute standards. Because deprivation is relative and not absolute, it is often the case that those who are the most deprived in an objective sense, are not the ones most likely to experience deprivation (Crosby, 1976; Banerjee, 2008). Indeed, it appears that people may find the confirmation of their expectations more important for a sense of fairness, than what they actually receive (Greenberg, 1982; Van de Bos et al., 1996).

Consequently, a sense of relative deprivation arises when people feel unjustly or unfairly treated when they compare their circumstances to some standard - usually a reference group (Crosby, 1976; Hernes and Knudsen, 1992). Reference groups act as a frame of reference which individuals use to evaluate their achievements, aspirations and ambitions (Thompson and Hickey, 2005). Individuals can use themselves or a reference group in the past, as well as the present, as the comparison other with whom to compare their present outcomes (Crosby, 1976). The crucial factor is the comparator group in the development of a sense of relative deprivation. Thus, the intensity of the feeling of relative deprivation depends on the strength of expectations regarding entitlements that are perceived as fair and just to a particular standard or situation (Lind et al., 1998; Van Den Bos et al., 1996).

A number of preconditions for feelings of relative deprivation have been identified that include a knowledge of the possessions/standard of living of others, wanting what others possess, a sense of entitlement and a belief that it is feasible to acquire these possessions (Crosby, 1976). Irish nationals who have experienced difficulties in the labour market such as engagement in insecure precarious type jobs, unemployment and low income are more likely to make unfavourable comparisons with others and feel a strong sense of relative deprivation. Non-Western immigrants are even more likely to be at a relative disadvantage in the labour market than natives or immigrants from Europe and the Western hemisphere when compared to natives with comparable demographic characteristics and skill levels. This waste of human capital likely induces a feeling of bitterness among these immigrants and informs their attitudes towards the host country (Valenta, 2008). Work experiences in the labour market are often compounded for immigrants particularly from Non-Western countries by implicit and explicit life-long forms of discrimination that negatively affected immigrants' life chances and depressed their sense of well-being across generations (Safi, 2010:171).

Though immigrants tend to work in poorer jobs, have higher levels of unemployment and suffer higher levels of discrimination than comparable Irish natives they may not feel a sense of deprivation. First-generation immigrants may perceive no unfairness at work because they are unaware that others possess $x$ and therefore no resentment can occur. Similarly, immigrants may not want x, or feel entitled to it, or believe that it is feasible to attain. Moreover, first-generation immigrants are likely to compare with the conditions in the country of origin rather than with their economic experiences in the labour market in the host country. Studies of immigrants from Eastern Europe indicated a relatively high level of contentment with their jobs and working conditions since their arrival in Ireland (Moriarty et al, 2014; Turner et al, 2009).

Alternatively, second generation immigrants with non-western or Eastern European parents are more likely to compare with native Irish and hold similar expectations regarding their material conditions. Consequently, second generation immigrants are likely to have a similar profile as natives with those in poor and precarious jobs characterised by low income and periods of unemployment more likely to make unfavourable comparisons with others and feel a strong sense of relative deprivation.

\section{RESEARCH MODEL AND HYPOTHESES}

The basic model proposed here is that labour market experiences will act as a mediator variable between the three comparator groups providing a partial explanation of differences in levels of trust in political institutions, democracy and social integration (fig.1).

Our dependent measures focus on trust in political institutions, satisfaction with democracy and generalised trust in others. Studies in Europe indicate that immigrants generally exhibit higher levels of trust in public institutions, trust and satisfaction than natives (Maxwell, 2008; 2010; Roder and Muhlau, 2011). On the other hand many of those first-generation immigrants from non-western countries are likely to have left authoritarian type regimes and given their early socialising experiences may have a weaker attachment to democratic civic values than natives. 
An individual's key formative years of political socialisation is usually defined as that period from mid-adolescence to early adulthood - age 15 to 25 (Grasso, 2014). People acquire values and opinions grounded in their specific historical life experiences that tend to emerge in these formative years and remain stable thereafter (Ventura, 2016; Prior, 2010; Ghitza and Gelman, 2014). As a result immigrants from non-democratic regimes are more likely to display stronger authoritarian attitudes and are less likely to engage in democratic political activities and outlook than either immigrants from democratic countries or host country natives (Rice and Feldman, 1997; Bueker, 2005; Bilodeau, 2008). Evidence from Canada and Australia indicate that the more authoritarian the country of origin of immigrants' the weaker their democratic support and the lower their participation in political activities (Bilodeau, 2008; Bilodeau et al., 2010). Length of time spent in the host country is also likely to weaken established authoritarian attitudes. However, over half (56\%) of the immigrants in our sample have lived in Ireland for only ten years or less, 36 per cent between ten and fifteen years and nine per cent for longer.

\section{Labour market experiences}

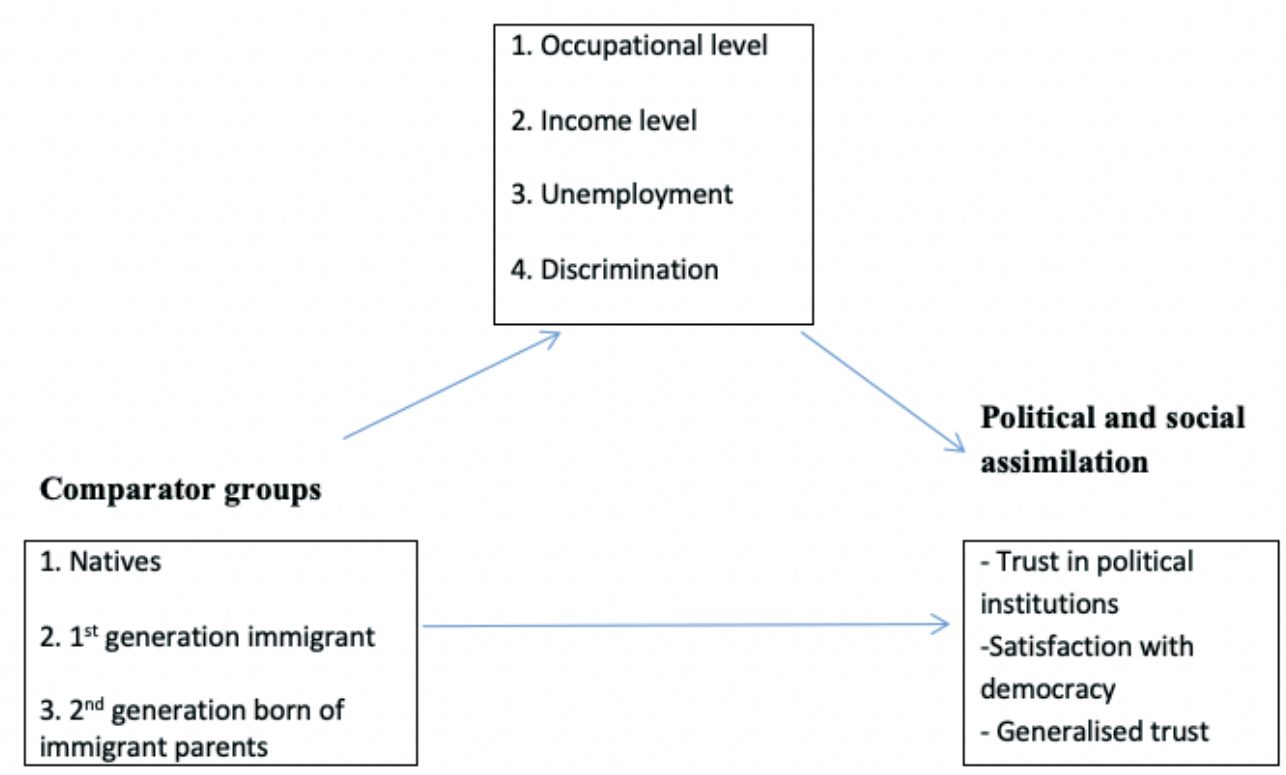

Figure 1: Labour market experiences, immigrants and political assimilation

Thus, we first explore whether first-generation immigrants many of them originating from non-Western authoritarian regimes and with less than ten years residence will ceteris paribus have a weaker attachment to democratic institutions and have lower levels of generalised trust. While a majority of the Eastern European immigrants in our sample emigrated from Poland, an established democracy only after 1990, their experience of democratic institutions likely lacked the political and cultural continuity of mainstream countries of the European Union. Indeed in recent years there has been a rise in authoritarianism in many Eastern European countries particularly Poland and Hungary (ÁGH, 2014).

Such immigrants from non-Western and East European countries may be more likely to have a weaker attachment to democracy and the institutions of the state such as the national parliament (hypothesis 1). Yet as outlined earlier first-generation immigrants may not experience a sense of relative deprivation compared to natives since they commonly compare their conditions in the host country to their country of origin. In that case differences in political values and activities between first-generation immigrants and natives may be insignificant. Alternatively, hypothesis 1 may hold for second-generation immigrants who are more likely to compare with natives and feel a sense of deprivation if their perceived material conditions compare adversely with the latter. Given the limited time most first-generation immigrants have resided in Ireland and likely relatively brief interaction with natives in a social arena it can be predicted that first-generation immigrants will have lower levels of generalised trust compared to natives (hypothesis 2). 
An explicit aspect in our conceptual approach is that peoples' experiences in the labour market will have a significant impact on their political and social values. Immigrant and native orientation to these political and social values are we propose likely to be strongly influenced by their experiences at work by the jobs they do, level of income and the risks of unemployment. As noted earlier, immigrants tend to experience greater difficulties in the labour market than natives. Consequently, it can be expected that first-generation immigrants will be employed in lower level occupations, have greater difficulty coping with their income, more likely to experience unemployment and discrimination compared to native Irish (hypothesis 3 ).

Our more substantive focus is the extent to which the labour market experiences of first and second-generation immigrants influence political and social values in a similar manner to natives. Given the centrality of the labour market in determining material life chances it may be the case that its effect on the political and social measures will be similar for both immigrants and natives. Alternatively, the likelihood of feelings of relative deprivation arising in a social situation depends on who are identified as the individual or group comparator. In the case of first-generation non-western immigrants, the comparison may not be with the labour market conditions of natives but with the conditions in the country of origin. Thus, we might expect that the effects of labour market conditions on social and political attitudes will be different for first-generation immigrants compared to natives and second-generation immigrants. Specifically, labour market characteristics are likely to be a significant factor for natives and secondgeneration immigrants in determining levels of generalised trust, political attitudes and behaviour and satisfaction with democracy but not for first generation immigrants (hypothesis 4).

\section{DATA AND METHODOLOGY}

The European Social Survey (ESS) is a large-scale, cross-national, and longitudinal survey research programme on how Europeans think about family, work, religion, politics and society. Respondents are individually interviewed and the survey is repeated approximately every two years. Our analysis is based on the combined five waves from 2008 to 2016. Apart from the UK the main source of immigrants into Ireland since 2000 has come from Eastern Europe (particularly Poland). The number of respondents for these five waves is 10,915 composed of 9999 natives, 750 first-generation comprised of non-western and Eastern European immigrants, and 166 second-generation of non-western immigrant parents. Immigrants from Africa account for 45 per cent from non-Western countries, Asians for 33 per cent, South Americans for 13 per cent and Middle East for eight per cent. First generation refers to those immigrants who have migrated to Ireland from either a non-Western or East European country while second generation refers to those born in Ireland of immigrant parents.

A crucial institution of European countries is the system of democratic government in which rulers are held accountable for their actions in the public realm by citizens, acting indirectly through their elected representatives (Schmitter and Karl, 1991: 76; Ichilov, 1990: 1). An important factor in the integration of immigrants is the extent of their trust and confidence in the political institutions of the host country moulded through daily interactions and cooperative relations to create a culture of trust, reciprocity and cooperation (Newton and Norris, 2000). Five items comprising one aggregate measure (Alpha=0.84) are used to assess a respondent's trust and confidence in the Irish political system as follows: Irish politicians; Irish political parties; the country's parliament; the Irish legal system and the police. A separate item is used to assess how satisfied respondents are with the way democracy works in Ireland (table 1).

In addition, a social measure is used to examine the extent to which first and second-generation non-western immigrants trust people in Irish society compared with natives. The literature on interpersonal trust identifies two main types: particularised trust toward immediate known people in everyday interactions and generalised trust toward people who are more socially distant such as fellow citizens and even strangers (Stolle et al., 2008; Uslander, 2002). Generalised trust arises from an individual's predispositions due to early life socialisation and personality type and more crucially from concrete experiences of trustworthiness in social interaction with others generally (Freitag and Traunmuller, 2009; Kongshpj, 2018). We focus on generalised trust as a measure of the degree of social integration of non-western-immigrants since high levels of generalised trust are held to be a signal of integration or assimilation into mainstream society (Kongshpj, 2018; Harris Hyun-Soo, 2018). The classic measure of generalized trust is the most-people trust question (Bauer and Freitag, 2018) with items designed to capture optimism and unconditional faith in strangers and unknown others (Uslaner 2002). Here we use three items (alpha=0.76) focused on whether respondents believe that most people can be trusted; that most people would try to take advantage of you if they got 
the chance and that most of the time people try to be helpful. Additionally, in the multivariate statistics educational level, age and gender are included in the analysis.

Table 1: Description of measures

\begin{tabular}{|c|c|c|}
\hline & Dependent social and political measures & $\begin{array}{l}\text { Alpha } \\
\text { reliability } \\
\text { score }\end{array}$ \\
\hline & Trust in democratic institutions & \\
\hline \multirow[t]{4}{*}{$\begin{array}{l}\text { Trust in politics and state } \\
\text { institutions }\end{array}$} & $\begin{array}{c}\text { Composed of } 5 \text { items: How much do you personally trust each of the following: } 1 \text {. country's } \\
\text { parliament? 2. Politicians? } 3 \text {. Political parties. } 4 \text {. The legal system? } 5 \text {. The police? } \\
\text { Scored } 0=\text { no trust al all to } 10=\text { complete trust. Overall score is divided by } 5 \text { to retain the range } \\
\text { between } 0 \text { and } 10 .\end{array}$ & 0.84 \\
\hline & Satisfaction with democracy & \\
\hline & $\begin{array}{l}\text { On the whole, how satisfied are you with the way democracy works in this country? } \\
\qquad \text { Scored } 0=\text { Extremely dissatisfied to } 10=\text { Extremely satisfied. }\end{array}$ & / \\
\hline & Sustaining a democratic culture & \\
\hline \multirow[t]{2}{*}{$\begin{array}{l}\text { Generalised trust in } \\
\text { people }\end{array}$} & $\begin{array}{l}\text { Composed of } 3 \text { items: Generally speaking, would you say that most people can be trusted, or that } \\
\text { you can't be too careful in dealing with people?; Do you think that most people would try to take } \\
\text { advantage of you if they got the chance, or would they try to be fair?; Would you say that most of the } \\
\text { time people try to be helpful or that they are mostly looking out for themselves? Scored } 0=\text { No trust } \\
10=\text { High trust. Overall score is divided by } 3 \text { to retain the range between } 0 \text { and } 10 \text {. }\end{array}$ & 0.76 \\
\hline & Labour market measures & \\
\hline Occupation & $\begin{array}{l}\text { Occupations are categorised as follows: } 1=\text { Lower manual; } 2=\text { Higher manual (skilled); } 3=\text { Routine } \\
\qquad \text { white collar; } 4=\text { Higher white collar/professional. }\end{array}$ & / \\
\hline Income & $\begin{array}{l}\text { Satisfaction with income scored } 1 \text { =Very difficult to cope; } 2=\text { Difficult to cope; } 3=\text { Coping; } 4 \text { =Coping } \\
\text { comfortably. }\end{array}$ & / \\
\hline Unemployment periods & Were you ever unemployed and seeking work for more than three months. Scored 1=Yes; $0=$ No. & / \\
\hline \multirow[t]{2}{*}{ Discriminated against } & $\begin{array}{l}\text { Would you describe yourself as being a member of a } \\
\text { group that is discriminated against in this country? Scored } 1=\text { Yes; } 0=\text { No. }\end{array}$ & / \\
\hline & Controls & \\
\hline Gender & Scored $1=$ Males; $0=$ Females & / \\
\hline Education & Scored $1=$ Up to 13 years of education; $0=$ More than 13 years & / \\
\hline Age & Scored $1=$ over $45 ; 0=$ less than 45 & / \\
\hline
\end{tabular}

The rationale for including Eastern Europeans in the analysis is that they represent the most notable single group of immigrants in the recent flows into Ireland. Tests for differences between the non-western $(\mathrm{N}=456)$ and East European immigrants $(\mathrm{N}=294)$ indicates no statistical significant differences on the three dependent measures of trust in political institutions, satisfaction with democracy and generalised trust (based on T-tests).

Table 2: Means and significant differences between Non-Western and Eastern European immigrants

\begin{tabular}{cccccc}
\hline & $\begin{array}{c}\text { Non-Western } \\
\text { immigrants }\end{array}$ & $\begin{array}{c}\text { Eastern } \\
\text { European } \\
\text { immigrants }\end{array}$ & $\begin{array}{c}\text { Two-tailed } \\
\text { T-test }\end{array}$ & Significance & N \\
\hline \hline Satisfaction with democracy & 6.2 & 6.47 & .12 & $\mathrm{~ns}$ & 673 \\
Trust in state institutions & 5.0 & 4.9 & .14 & $\mathrm{~ns}$ & $\mathrm{~ns}$ \\
Generalised trust in people & 5.4 & 5.6 & .87 & 730 \\
\hline
\end{tabular}

* ns $=$ Not significant at the 0.01 level

A respondent's labour market experience is assessed using four measures. Occupational range from lower manual to professional level is correlated strongly with income level, working conditions and security of employment; 
satisfaction with income gauges the adequacy of an individual's income; the extent of perceived discrimination; and whether a respondent was ever unemployed for more than three months. Overall 43 per cent of first generation immigrants in our sample had experienced unemployment for more than three months and for 75 per cent of this cohort the period of unemployment had occurred within the last five years. Thus this period of unemployment reported by first generation immigrants likely occurred for most while working and seeking employment in the Irish labour market. Finally in the multivariate statistics educational level, age and gender are included as controls in the analysis.

\section{RESULTS}

First-generation immigrants from non-western and Eastern European countries have statistically significantly lower levels of generalised trust than natives and second-generation immigrants confirming hypothesis 2 that firstgeneration immigrants will have lower levels of generalised trust compared to natives (table 3 ). This is perhaps not surprising as new immigrants are likely to feel more vulnerable and have limited contact, at least initially, with natives. For second-generation immigrants' social integration into networks that included natives are more likely and indeed mean generalised levels of trust are highest for this category. In contrast first-generation immigrants have significantly higher levels of trust in politicians and political institutions and satisfaction with the way democracy works in Ireland compared to natives. There are no significant differences in these measures between natives and second-generation immigrants. Thus, on these two substantives measures there is no support for hypothesis 1 . As noted earlier there are mitigating factors for the lower mean level of generalised trust of first-generation immigrants compared to natives.

Table 3: Ethnic origin and political and social measures

\begin{tabular}{ccccc}
\hline & $\begin{array}{c}\text { Generalised } \\
\text { trust in people }\end{array}$ & $\begin{array}{c}\text { Trust in } \\
\text { politicians }\end{array}$ & $\begin{array}{c}\text { Satisfaction } \\
\text { with democracy }\end{array}$ & N \\
\hline \hline Native Irish & 5.68 & 4.35 & 4.96 & $9561-9959$ \\
First generation immigrants & $5.45^{\star *}$ & $4.96^{\star *}$ & $6.3^{\star *}$ & $(1 \& 3)$ \\
Second generation immigrants & $(1 \& 3)$ & $(1)$ & 4.91 & $159-755$ \\
\hline
\end{tabular}

First-generation immigrants have significantly lower mean occupational levels and are less likely to report being able to cope with their income compared to natives and second-generation immigrants (table 4). They are also significantly more likely to have experienced periods of unemployment for more than three months and be a member of a group that is discriminated. There are no significant differences between natives and second-generation immigrants on these four measures. Thus, first-generation immigrants appear to be significantly disadvantaged in the labour market compared to natives and second-generation immigrants. These results provide substantial support for hypothesis 3 that first-generation immigrants fare least well in the labour market compared to natives and second-generation immigrants.

Table 4: Ethnic origin and LM characteristics (means and Anovas reported)

\begin{tabular}{ccccc}
\hline & $\begin{array}{c}\text { Occupational } \\
\text { level }\end{array}$ & Income & Unemployed & Discrimination \\
\hline \hline Native Irish & 2.8 & 2.94 & $0.26^{* *}$ & 0.04 \\
First generation immigrants & $2.55^{* *}$ & $2.66^{* *}$ & 0.43 & $0.17^{\star *}$ \\
& $(1 \& 3)$ & $(1 \& 3)$ & 0.36 & 0.07 \\
Second generation immigrants & 2.97 & 2.95 & $0.3)$ \\
\hline
\end{tabular}


To test the assumption in our model (fig.1) that labour market experiences are associated with different levels of political values and social integration a number of linear regressions are reported in table 5 controlling for age, education and gender. When labour market characteristics are excluded from equation 1 then there is a significant difference in the levels of generalised trust between natives and first-generation immigrants confirming hypothesis 2. However, when labour market characteristics are included the significant difference in levels of generalised trust between natives and first-generation immigrants disappears due in large measure to the effects of perceived adequacy of income. Thus, it appears that levels of generalised trust are strongly influenced by respondent's perception of the adequacy of income level. The results in equations 2 and 3 support the previous descriptive and provide little support for hypothesis 1 that non-western first-generation immigrants would have lower trust in politics and satisfaction with democracy controlling for labour market characteristics and gender, age and education.

Table 5: Impact of origin on political and social measures controlling for LM characteristics, gender, age and educationa: Standardised coefficients reported: (T-values in parentheses)

\begin{tabular}{|c|c|c|c|}
\hline & $\begin{array}{c}\text { Mean generalised } \\
\text { trust }\end{array}$ & $\begin{array}{l}\text { Mean trust in } \\
\text { politicians }\end{array}$ & $\begin{array}{c}\text { Mean satisfaction with } \\
\text { democracy }\end{array}$ \\
\hline 1st Generation & ns $(-.9)$ & $0.11^{* *}(10.8)$ & $0.18^{\star \star}(17.3)$ \\
\hline 2nd Generation & ns (2.1) & ns (1.8) & ns $(-0.2)$ \\
\hline \multicolumn{4}{|l|}{ Reference category: Natives } \\
\hline & \multicolumn{3}{|c|}{ Labour market characteristics } \\
\hline \multicolumn{4}{|l|}{ Occupation } \\
\hline Higher manual & ns (1.9) & ns $(0.7)$ & ns (0.6) \\
\hline Routine WC & ns (1.5) & $0.06^{\star \star}(4.4)$ & ns (2.3) \\
\hline Higher WC & $0.07^{\star \star}(4.7)$ & $0.06^{\star \star}(4.3)$ & ns (2.3) \\
\hline \multicolumn{4}{|l|}{ Reference category: Lower manual } \\
\hline \multicolumn{4}{|l|}{ Income } \\
\hline 2. Difficult & $0.11^{\star \star}(6.4)$ & $0.09 * *(5.2)$ & ns (1.3) \\
\hline 3. Coping & $0.24^{\star *}(11.8)$ & $0.21^{* *}(10.2)$ & $0.1^{\star \star}(5.0)$ \\
\hline 4. Comfortable & $0.31^{* *}(16.0)$ & $0.3^{* *}(14.7)$ & $0.19^{\star *}(9.2)$ \\
\hline \multicolumn{4}{|l|}{ Reference category: Very difficult } \\
\hline Unemployed & $-0.04^{\star \star}(3.3)$ & $-0.08^{\star \star}(7.7)$ & $-0.08^{\star \star}(7.3)$ \\
\hline \multirow[t]{2}{*}{ Discriminated against } & $-0.04^{* *}(4.1)$ & $-0.08^{\star \star}(7.7)$ & $-0.08^{\star \star}(7.7)$ \\
\hline & \multicolumn{3}{|c|}{ Controls } \\
\hline Gender/male & ns $(1.0)$ & $0.06^{\star *}(5.4)$ & $0.09^{\star *}(7.9)$ \\
\hline Over 45 age & ns (2.0) & $0.07^{\star \star}(6.4)$ & $0.07^{\star \star}(6.1)$ \\
\hline Under 13 years of Education & $-0.08^{\star \star}(7.2)$ & $-0.07^{\star \star}(6.0)$ & $-0.1^{\star *}(8.7)$ \\
\hline R2 & 0.07 & 0.09 & 0.09 \\
\hline F score & $55^{\star \star}$ & $70^{* \star}$ & $67^{\star \star}$ \\
\hline $\mathrm{N}$ & 9401 & 9028 & 9048 \\
\hline
\end{tabular}

\footnotetext{
${ }^{*} \mathrm{P}<0.01 ;{ }^{* * P}<0.001$
}

a The regressions were also run specifying year dummies for the five ESS rounds. While there were differences in the results in some rounds for the dependent measures the impact on the coefficients of the three cohorts (natives, First and second generation immigrants) and labour market characteristics remained essentially unchanged. 
In table 6 the association between labour market characteristics and the three dependent measures are assessed by running separate equations for natives, first and second-generation immigrants with the same controls included. Here only the coefficients for the labour market measures are reported. There is a relatively consistent pattern with variance in labour market factors significantly associated with trust in politics and satisfaction with democracy for natives but having no significant impact for first-generation immigrants. While levels of generalised trust are also influenced by all labour market measures for natives it is the experience of unemployment and discrimination that is strongly associated with lower levels of generalised trust. These results confirm in the main hypothesis 4 that labour market characteristics are likely to be a significant factor for natives in determining levels of generalised trust, political attitudes and satisfaction with democracy.

Table 6: Impact of LM characteristics on political and social measures by ethnic origin (Standardised beta coefficients reported: T-values in parentheses)

\begin{tabular}{|c|c|c|c|c|c|c|c|c|c|}
\hline & \multicolumn{3}{|c|}{ Generalised trust in people } & \multicolumn{3}{|c|}{ Trust political institutions } & \multicolumn{3}{|c|}{ Satisfaction with democracy } \\
\hline & Natives & $\begin{array}{c}1^{\text {st }} \\
\text { Gen }\end{array}$ & $\begin{array}{l}2^{\text {nd }} \\
\text { Gen }\end{array}$ & Natives & $\begin{array}{c}1^{\text {st }} \\
\text { Gen }\end{array}$ & $\begin{array}{l}2^{\text {nd }} \\
\text { Gen }\end{array}$ & Natives & $\begin{array}{c}1^{\text {st }} \\
\text { Gen }\end{array}$ & $\begin{array}{l}2^{\text {nd }} \\
\text { Gen }\end{array}$ \\
\hline \multicolumn{10}{|l|}{ Occupation } \\
\hline $\begin{array}{l}\text { Higher } \\
\text { managerial }\end{array}$ & $\mathrm{ns}(1.7)$ & $\mathrm{ns}(1.0)$ & $\mathrm{ns}(-.3)$ & $\mathrm{ns}(0.2)$ & $\mathrm{ns}(1.6)$ & $\mathrm{ns}(0.8)$ & $\mathrm{ns}(0.2)$ & $\mathrm{ns}(1.6)$ & $\mathrm{ns}(1.1)$ \\
\hline $\begin{array}{l}\text { Routine white } \\
\text { collar }\end{array}$ & $\mathrm{ns}(1.0)$ & $\mathrm{ns}(1.3)$ & $\mathrm{ns}(0.5)$ & $0.06^{\star *}(4.1)$ & $\mathrm{ns}(1.4)$ & $\mathrm{ns}(1.3)$ & $\mathrm{ns}(2.4)$ & $\mathrm{ns}(0.3)$ & $\mathrm{ns}(0.8)$ \\
\hline $\begin{array}{l}\text { Higher white } \\
\text { collar }\end{array}$ & $0.06^{\star *}(4.1)$ & $\mathrm{ns}(2.5)$ & $\mathrm{ns}(0.1)$ & $0.06^{\star *}(3.8)$ & $\mathrm{ns}(1.4)$ & $\mathrm{ns}(1.9)$ & $\mathrm{ns}(2.4)$ & $\mathrm{ns}(0.2)$ & $\mathrm{ns}(0.7)$ \\
\hline Ref cat.: lower & manual & & & & & & & & \\
\hline \multicolumn{10}{|l|}{ Income } \\
\hline Difficult & $0.11^{\star \star}(6.3)$ & $\mathrm{ns}(1.1)$ & $\mathrm{ns}(1.3)$ & $0.09 * *(4.9)$ & $\mathrm{ns}(1.4)$ & $\mathrm{ns}(0.2)$ & $\mathrm{ns}(1.0)$ & $\mathrm{ns}(1.1)$ & $\mathrm{ns}(0.4)$ \\
\hline Coping & $0.26^{* *}(11.9)$ & $\mathrm{ns}(1.6)$ & $\mathrm{ns}(1.8)$ & $0.22^{* *}(10.0)$ & $\mathrm{ns}(1.4)$ & $\mathrm{ns}(1.3)$ & $0.12^{\star *}(5.2)$ & $\mathrm{ns}(0.3)$ & $\mathrm{ns}(0.1)$ \\
\hline Comfortable & $0.34^{* *}(16.0)$ & $\mathrm{ns}(1.0)$ & $0.46^{\star}(3)$ & $0.31^{* *}(14.4)$ & $\mathrm{ns}(1.6)$ & $\mathrm{ns}(2.1)$ & $0.2^{\star \star}(9.0)$ & $\mathrm{ns}(1.4)$ & $\mathrm{ns}(1.7)$ \\
\hline Ref. cat.: Very & difficult & & & & & & & & \\
\hline Unemployed & $-0.03^{*}(2.7)$ & $-0.12^{\star \star}(2.8)$ & $\mathrm{ns}(1.7)$ & $-0.09 * *(8.2)$ & $\mathrm{ns}(0.6)$ & $\mathrm{ns}(0.9)$ & $-0.08^{\star \star}(7.2)$ & $\mathrm{ns}(-1.3)$ & $\mathrm{ns}(0.8)$ \\
\hline $\begin{array}{c}\text { Feel } \\
\text { discriminated } \\
\text { against }\end{array}$ & $-0.04^{\star \star}(3.8)$ & $-0.11^{\star *}(2.6)$ & $\mathrm{ns}(0.8)$ & $-0.08^{\star \star}(7.8)$ & $\mathrm{ns}(-0.5)$ & $\begin{array}{c}-0.28^{\star *} \\
(3.5)\end{array}$ & $-0.1^{* *}(8.8)$ & $\mathrm{ns}(0.5)$ & $n s(-2.2)$ \\
\hline
\end{tabular}

* $\mathrm{P}<0.01 ;{ }^{*} \mathrm{P}<0.001$. ns: not significant

\section{CONCLUSION}

This paper examined the extent of the political and social integration of first and second generation immigrants and in particular the influence of their labour market experiences through a comparison with native Irish. Political and social assimilation was assessed by the extent to which the attitudes of immigrants towards political and social institutions converged or diverged from the attitudes of native Irish respondents. Our results indicate that first generation non-Western and Eastern European immigrants reported significantly higher levels of trust in politicians and political institutions and satisfaction with democracy compared to natives. This confirms previous research 
findings of higher levels of political trust and satisfaction among first generation immigrants compared to natives (Safi, 2010; Maxwell, 2012). In contrast previous studies indicating that second-generation immigrants exhibit similar or lower levels of political trust and satisfaction compared to natives are not supported here (Roder and Muhlau, 2011; Maxwell, 2012). There was no significant difference in any of the political measures between natives and second-generation immigrants. These results need to be viewed with some caution due to the relatively small sample of second-generation respondents. Disgruntled or disappointed second-generation immigrants in many European countries such as Germany, Denmark (Nannestad, 2004) France and the UK are children of parents that migrated to the host country as far back as the 1950s. These initial groups of immigrants often clustered together to form relatively enduring enclaves in the host society. Alternatively, the relatively recent inflow of immigrants into Ireland and the apparent geographical dispersal across urban and rural settings has militated against the formation of immigrant minorities residing in specific enclave areas (Turner, 2010; Klaesson and Öner, 2020).

A second substantive area of focus was to test whether labour market experiences acted as mediator between first- and second-generation immigrants and the extent of political and social assimilation into the host country. As expected, first-generation immigrants were significantly disadvantaged in the labour market (Maani, 1994), being significantly more likely to work in lower level occupations, have lower satisfaction with their income and more likely to experience unemployment and discrimination compared to natives and second-generation immigrants (O'Connell and McGinty, 2008). In the main there was a consistent relationship between the labour market factors and the measures of political and social assimilation (Neuman, 2018) in the expected direction for all respondents as predicted by our basic mediation model. Occupations below higher white-collar level, difficulty with income, exposure to bouts of unemployment and discrimination were associated with lower mean levels of generalised trust, trust in political institutions and satisfaction with democracy. However, this association between labour market experiences and levels of generalised trust, political attitudes and satisfaction with democracy (Bauer, 2018) was only significant for natives. There was a relatively consistent pattern with variance in labour market factors significantly associated with trust in politics and satisfaction with democracy for natives but having no significant impact for first or second-generation immigrants.

Thus, our proposition that experiences in the labour market would be an important factor in the social and economic integration of first and second-generation immigrants into the host society receives scant support from these results. It seems that first-generation immigrants' attachment to the political institutions of the host country are likely influenced more by a comparison with conditions in their country of origin rather than how they fare in labour market of the host country. As such first-generation immigrants do not experience a sense of deprivation as their comparator is most likely with conditions in their country of origin and not experiences in the host country labour market. Moreover, studies of Polish workers show that the motivation to migrate to Ireland stems not just from instrumental factors but also from aspirations for different lifestyles, new opportunities and self-development (Krings et al, 2013). Such aspirations may also be a motivating characteristic of immigrants from non-Western countries. A notable feature of both non-Western and Eastern European first-generation immigrants is significantly higher mean levels of years in education. Over 65 per cent of these first-generation immigrants reported over 13 years of full-time education compared to 50 per cent of native Irish (for second generation immigrants the difference was even larger). For the Africans in our sample it was 63 per cent, 74 per cent for South Americans, 80 per cent for Middle Eastern, 71 per cent for Asians and 66 per cent for Eastern Europeans. These first-generation immigrants are likely to be on average better educated and qualified than those remaining in their country of origin with longer term aspirations to progress in the host country. Thus, apart from the absence of any sense of deprivation their commitment to the political institutions and social integration is likely to be enhanced by aspirations to seek opportunities and advance in the host society.

Overall, the inflow of first generation non-Western and East European into Ireland does not appear to undermine or dilute the fundamental political institutions and values that are integral to a democratic society. Nor it seems is there any difference in the attachment to political institutions between second generation immigrants and natives. This may indicate that the expectations and aspirations of second-generation immigrants have largely been realised. However further research is required to confirm the experiences and attitudes of second-generation immigrants in Ireland. 


\section{References}

ÁGH, A. (2014). 'The Decline of Democracy in Est Central Europe: The Lost Decade of Democracy in the ECE Democratization', Journal of Comparative Politics, 7 (2): 4-33.

Banerjee, R. (2008). 'An Examination of Factors Affecting Perception of Workplace Discrimination', Journal of Labour Research, 29: 380-401.

Barrett, A., Bergin, A. and Duffy, D. (2006). 'The Labour Market Characteristics and Labour Market Impacts of Immigrants in Ireland', The Economic and Social Review, 37 (1): 1-26.

Barrett, A., McGuinness, S. and O'Brien, M. (2008). The Immigrant Earnings Disadvantage Across the Earnings and Skills Distributions: The Case of Immigrants from the EU's New Member States in Ireland. Economic and Social Research Institute, Working Paper 236, Dublin: ESRI.

Barrett. A. and McCarthy. Y. (2007). 'Immigrants in a Booming Economy: Analysing their Earnings and Welfare Dependence', Labour, 21(4): 789-808.

Bauer, P. C. (2018). 'Unemployment, Trust in Government, and Satisfaction with Democracy: An Empirical Investigation'. Socius, Sociological Research for a Dynamic World. https://doi. org/10.1177/2378023117750533

Bauer, P. and Freitag, M. (2018). 'Measuring Trust', In Eric Uslaner, ed., Oxford Handbook of Social and Political Trust, pp. 15-36. Oxford University Press: Cambridge.

Bilodeau, A., McAllister, I. and Kanji, M. (2010). 'Adaptation to Democracy among Immigrants in Australia', International Political Science Review, 31(2): 141-165.

Bilodeau, A. (2008). 'Immigrants' Voice through Protest Politics in Canada and Australia: Assessing the Impact of Pre-migration Political Repression', Journal of Ethnic and Migration Studies 34(6): 975-1002.

Borjas G. (2006). 'The Impact of Immigration and the Labour Market', paper presented at the Conference on Labor and Capital Flows, International Monetary Fund, Jointly hosted by the Vienna Institute and National Bank of Poland.

Borjas, G. (1999). 'The economic analysis of immigration', in Ashenfelter, O. and Card, D.E. (eds) Handbook of Labor Economics Vol. 3. Amsterdam: Elsevier Science/North-Holland, 1697-1760.

Brandi, M. (2001). 'Skilled Immigrants in Rome', International Migration, 39 (4), 101-116.

Breen, R. (2005). 'Foundations of a neo-Weberian class analysis', in Olin Wright, E. (ed) Approaches to
Class Analysis, Cambridge University Press, 3150

Butkus, A., Mačiulytè-Šniukienè, and David Avičienè. V. (2016). 'Factors influencing society's attitudes towards internal and external EU immigrants', Filosofija. Sociologija. 27(4), 292-303. Available from: https://www.researchgate.net/ publication/312625554_Factors_influencing_ society's_attitudes_towards_internal_and_ external_EU_immigrants

Crosby, F. (1976). 'A model of egoistical relative deprivation', Psychological Review, 83 (2), 85-110.

CSO (2018). Census 2016, Non-Irish Nationalities Living in Ireland, available https://www.cso.ie/en/ csolatestnews/presspages/2018/census2016-nonirishnationalitieslivinginireland/

De Rooij, E. (2012). 'Patterns of Immigrant Political Participation: Explaining Differences in Types of Political Participation between Immigrants and the Majority Population in Western Europe', European Sociological Review 28 (4), 455-481.

Evers, A., and Van der Flier, H. (1998). Ethnic minorities on the labour market'. In P. J. D. Drenth, H. Thierry, and C. J. De Wolff (Eds.), Handbook of work and organizational psychology. Hove, UK: Psychology Press.

Fargues, P., Papademetriou, D., Salinari, G. and Sumption, M. (2011). 'Shared Challenges and Opportunities for EU and US Immigration Policymakers', Florence, European University Institute/Washington, Migration Policy Institute, 2011EU-US Immigration Systems, 2011/20, Final Report. Retrieved from Cadmus, European University Institute Research Repository, at: http:// hdl.handle.net/1814/19074

Finch, T., Latorre, M. C., Pollard, N. and Rutter, J. (2009). 'Shall We Stay or Shall We Go? Re-migration Trends among Britain's Immigrants', Institute for Public Policy Research, London.

Fix, M., Papademetriou, D.G., Batalova, J., Terrazas, A., Yi-Ying Lin, S. and Mittelstadt, M. (2009). Migration and the Global Recession. Washington: Migration Policy Institute.

Friedberg, R. (2000). 'You Can't Take It With You? Immigrant Assimilation and the Portability of Human Capital', Journal of Labour Economics, 18 (2), 221-251.

Freitag, M. and Traunmüller, R. (2009). 'Spheres of trust: An empirical analysis of the foundations of particularised and generalised trust', European Journal of Political Research, 48(6), 782-803. 
Garson, J. P. and Loizillon, A. (2003). 'Changes and challenges: Europe and migration from 1950 to present', Paper presented at the conference on the Economic and Social Aspects of Migration, European Commission: Brussels, 21-22 January.

Giddens, A. (1973). The Class Structure of the Advanced Societies. London: Hutchinson.

Goldthorpe, J. H. (1980). Social Mobility and Class Structure in Modern Britain, Oxford: Clarendon Press.

Grasso M. T. (2014). 'Age, period and cohort analysis in a comparative context: Political generations and political participation repertoires in Western Europe'. Electoral Studies 33, 63-76.

Greenberg, J. (1982). 'Approaching Equity and Avoiding Inequity in Groups and Organisations' in Greenberg, J. and Cohen, R. (eds) Equity and Justice in Social Behaviour. New York: Academic Press.

Harris, K. (2018). 'Particularized Trust, Generalized Trust, And Immigrant Self-Rated Health: crossnational analysis of World Values Survey'. Public Health. 158. 10.1016/j.puhe.2018.01.039.

Hernes, G. and Knudsen, K. (1992). 'Norwegians' Attitudes Toward New Immigrants', Acta Sociologica 35: 123-139.

Hix, S. and Noury, A. (2007). 'Politics, Not Economic Interests: Determinants Of Migration Policies in the European Union', International Migration Review 41(1) March 2007, 182-205.

Ichilov, O. (1990). Political Socialization, Citizenship Education and Democracy. New York: Teachers College Press.

Klaesson, J., \& Öner, Ö. (2020). 'Ethnic Enclaves and Segregation-Self-Employment and Employment Patterns Among Forced Migrants'. Small Business Economics. https://doi.org/10.1007/s11187-01900313-y

Kongshøj, K. (2018). 'Acculturation and Expectations?' Nordic Journal of Migration Research, Vol. 8: Issue 1: 35-46.

Krings, F., \& Olivares, J. (2007). 'At The Doorstep To Employment: Discrimination against immigrants as a function of applicant ethnicity, job type, and raters' prejudice'. International Journal of Psychology, 42(6), 406-417. https://doi. org/10.1080/00207590701251721

Krings, T., Bobek, A., Moriarty, E., Salamońska, J. and Wickham, J. (2011). 'From Boom To Bust: Migrant Labour And Employers In The Irish Construction Sector', Economic and Industrial Democracy, 32(3), 459-476.

Krings, T., Bobek, A., Moriarty, E. and Wickham, J.
(2013). 'Polish Migration to Ireland: 'Free Movers' in the New European Mobility Space' Journal of Ethnic and Migration Studies 39(1), 87-103.

Lahav, G. (2004). Immigration and Politics in the New Europe. UK: Cambridge University Press.

Liebig, T., Kohis, S., and Krause, K. (2012). The Labor Market Integration Of Immigrants And Their Children In Switzerland, OECD Social, Employment and Migration Working Papers No. 128, Directorate for Employment, Labor and Social Affairs. Paris, France: OECD Publishing.

Lind, E., Kray, L. and Thompson, L. (1998). 'The Social Construction of Injustice: Fairness Judgements in Response to Own and Others' Unfair Treatment by Authorities', Organizational Behaviour and Human Decision Processes, 75 (1), 1-22.

Liversage, A. (2009). 'Vital Conjunctures, Shifting Horizons: High Skilled Female Immigrants looking for Work', Work, Employment and Society, 23 (1), 120-140.

McKay, S., Clark, N. and Paraskevopoulou, A. (2011). Precarious Work in Europe Causes and consequences for the Agriculture, Food and Tourism sectors. European Federation of Food, Agriculture and Tourism Trade Union.

Maani, S. (1994). 'Are Young Firstand Second Generation Immigrants at a Disadvantage in the Australian Labor Market?' The International Migration Review, 28(4), 865-882. doi:10.2307/2547161

Maxwell, R. (2012). Ethnic Minority Migrants in Britain and France: Integration Trade-Offs. New York: Cambridge Univ. Press.

Maxwell, R. (2010). 'Evaluating Migrant Integration: Political Attitudes Across Generations in Europe', International Migration Review, Vol. 44 Number 1 (Spring 2010), 25-52.

Maxwell, R. (2008). 'Assimilation, Expectations, and Attitudes: How Ethnic Minority Migrant Groups Feel About Mainstream Society'. DuBois Review 5(2):387-412.

Moriarty, E., Krings, T., Bobek, A., Salamońska, J. and Wickham, J. (2015). 'Large-scale migration in an open labour market: The Irish experience with post 2004 labour mobility and the regulation of employment standards' in Magdalena Bernaciak (ed), Market Expansion and Social Dumping in Europe, UK, Routledge, 10 - 28.

Moriarty, E., Wickham, J., Bobek, A., Daly, S., Krings, T. and Salamońska, J. (2014). 'Learning from Poland? What Recent Mass Immigration to Ireland Tells Us about Contemporary Irish Migration' in L. Brennan (ed.), Enacting Globalization: Multidisciplinary Perspectives on International Integration, London: 
Palgrave Macmillan, p. 146-155.

Murray, D. (2017). The Strange Death of Europe: Immigration, Identity and Islam, London: Bloomsbury Publishing.

Neuman, E. (2018). 'Source Country Culture and Labor Market Assimilation Of Immigrant Women In Sweden: Evidence From Longitudinal Data'. Rev Econ Household 16, 585-627. https://doi. org/10.1007/s11150-018-9420-6

Newton, K. and Norris, P. (2000). 'Confidence in Public Institutions: Faith, Culture, or Performance?' in S. Pharrand, and R. Putnam,(eds.), Disaffected Democracies, Princeton University Press, 52-73.

OECD (2003). Labour Shortages and the Need for Immigrants: A Review of Recent Studies,

Part II. Accessed January 28th 2020. Available: www. oecd.org/dataoecd/27/43/31857112.pdf

OECD (2001). 'The Employment Of Foreigners: Outlook And Issues In OECD Countries', Employment Outlook, Paris: Organisation for Economic Cooperation and Development. Accessed January 29th 2012.availalbe: http://www.oecd. org/employment/employmentpoliciesanddata/ o e c d e m p l o y m e n t o u t l o o k downloadableeditions1989-2011.htm.

Oesch, D. (2008). 'Explaining Workers' Support for Right-Wing Populist Parties in Western Europe: Evidence from Austria, Belgium, France, Norway, and Switzerland', International Political Science Review, 29(3), 349-373.

Rice, T. and Feldman, J. (1997). 'Civic Culture and Democracy from Europe to America', Journal of Politics, 59(4): 1143-72.

Röder, A. and Mühlau, P. (2012). 'Low Expectations or Different Evaluations: What Explains Immigrants' High Levels Of Trust In Host-Country Institutions?', Journal of Ethnic and Migration Studies, 38(5): 777-792.

Rustenbach, E. (2010). 'Sources of negative attitudes toward immigrants in Europe: A Multi-level analysis', International Migration Review , 44( 1), 53-77, Spring 2010.

Safi, M. (2010). 'Immigrants' life satisfaction in Europe: Between assimilation and discrimination', European Sociological Review, Vol. 26, Issue 2: 159-176.

Sassen S. (1999). Guests and Aliens. New York: The New Press.

Schaefer, R. (2008). Racial and Ethnic Groups. New Jersey: Pearson Education.
Schmitter, P. and Karl, T. (1991). 'What Democracy Is ... and Is Not', Journal of Democracy 2(3): 75-88.

Stolle, D, Saroka, S and Johnston, R (2008). 'When Does Diversity Erode Trust? Neighbourhood Diversity, Interpersonal Trust and the Mediating Effect of Social Interactions', Political Studies, vol. 56, no. 1: 57-75.

Thompson, W. and Hickey, J. (2005). Society in Focus. Boston, MA: Pearson.

Turner, T. (2010). 'Why are Irish Attitudes to Immigrants among the Most Liberal in Europe? Testing structural determinants in a comparative context', European Societies, 12(1): 25-44.

Turner, T., D'art, D. and Cross, C. (2009). 'Polish Workers in Ireland: A Contented Proletariat?' Labor Studies Journal, 34(1):112-126.

Van Den Bos, K., Vermunt, R. and Wilke, H. (1996). 'The Consistency Rule and the Voice Effect: The Influence of Expectations on Procedural Fairness Judgements and Performance', European Journal of Social Psychology, 26: 411-428.

Yılmaz, F. (2012). 'Right-Wing Hegemony And Immigration: How The Populist Far-Right Achieved Hegemony Through The Immigration Debate In Europe', Current Sociology, 60 (3): 368-381.

Markaki, Y. and Longhi, S. (2013). 'What Determines Attitudes to Immigration in European Countries? An Analysis at the Regional Level', Migration Studies, 1(3), November 2013, 311-337, https:// doi.org/10.1093/migration/mnt015

Uslaner, Eric. (2002.) The Moral Foundations of Trust. Cambridge: Cambridge University Press.

Valenta, M. (2008). 'The Workplace as an Arena for Identity and Affirmation and Social Integration of Immigrants', Forum: Qualitative Social Research, 9 (2): Art. 14, http://nbn- resolving.de/ urn:nbn:de:0114-fqs0802140.

Weber, M. (1978). Economy and Society: An Outline of Interpretive Sociology. Berkeley, CA: University of California Press.

Weber, H. (2015). 'National and Regional Proportion of Immigrants and Perceived Threat of immigration: A Three-Level Analysis in Western Europe', International journal of comparative sociology, Vol.56 (2): 116-140.

Zick, A., Küpper, B. and Hövermann, A. (2011). Intolerance, Prejudice and Discrimination A European Report . Nora Langenbacher FriedrichEbert-Stiftung Forum: Berlin. 